\title{
Occurrence and behavior of phosphorus-bearing minerals in metallurgical coke
}

\author{
Stanislav Gornostayev, Eetu-Pekka Heikkinen, Jyrki Heino and Timo Fabritius
}

Process Metallurgy Research Unit, University of Oulu, BOX 4300, Oulu, 90014, Finland

\begin{abstract}
The behavior of phosphorus-bearing minerals is characterized from coking coals to the feed coke and the blast furnace (BF) coke using scanning electron microscope and thermodynamic calculations. In coals, they are represented mostly by apatite (major phase, used for thermodynamic calculations), crandallite, gorceixite, goyazite, monazite and xenotime. Apatite fully transforms to $\mathrm{Ca}_{4} \mathrm{P}_{2} \mathrm{O}_{9}$ and $\mathrm{Ca}_{3} \mathrm{P}_{2} \mathrm{O}_{8}$ at coking temperatures. In the samples of $\mathrm{BF}$ coke, phosphorus-bearing phases are 5-30 $\mu \mathrm{m}$ in size. In the case of a closed system (inside pieces of coke, no gas), phosphorus is presented in the $\mathrm{BF}$ in the form of $\mathrm{Ca}_{4} \mathrm{P}_{2} \mathrm{O}_{9}$ and $\mathrm{Ca}_{3} \mathrm{P}_{2} \mathrm{O}_{8}$ up to $1250{ }^{\circ} \mathrm{C}$. Above this temperature, it will be transformed to $\mathrm{Fe}_{3} \mathrm{P}$ (stable until $1495^{\circ} \mathrm{C}$ ). A further rise in temperature leads to the transformation of $\mathrm{Fe}_{3} \mathrm{P}$ to $\mathrm{Fe}_{2} \mathrm{P}$ (stable up to $1930{ }^{\circ} \mathrm{C}$ - tuyere level of the $\mathrm{BF}$ ). In the case of an open system with intensive flow of $\mathrm{BF}$ gas, the formation of $\mathrm{Fe}_{3} \mathrm{P}$ from $\mathrm{Ca}_{4} \mathrm{P}_{2} \mathrm{O}_{9}$ and $\mathrm{Ca}_{3} \mathrm{P}_{2} \mathrm{O}_{8}$ will start at $1178{ }^{\circ} \mathrm{C}$. The $\mathrm{Fe}_{2} \mathrm{P}$ will appear near $1494-1495{ }^{\circ} \mathrm{C}$, and after that it will go to a molten state.
\end{abstract}

Keywords: coke; minerals; phosphorus, blast furnace 


\section{Introduction}

Phosphorus in steels can have positive and harmful effects. ${ }^{[1-7}$ and references therein] For example, as a solute in ferrite, it can cause higher strength and hardness with lower plastic properties. ${ }^{[5]}$ Dephosphorization of hot metal ${ }^{[8]}$ and recovery of phosphorus from steel slag ${ }^{[9]}$ are complex and costly processes. For these reasons, it is important to have data on the distribution and behavior of this element associated with all steel- and iron-making raw materials (pellets, ores, coke, coal, etc.).

As for blast furnace (BF) process, most coke producers blend coals to keep a phosphorus concentration of no more than $0.04 \% .{ }^{[10]}$ Phosphorus occurs in coals mostly in inorganic (mineral) form. ${ }^{[10-14]}$ Because of low concentrations of the element in coking blends (process requirements), the amount and size of the grains of related minerals are small. Therefore, it is not easy to find the grains for detailed investigations. However, the role of the minerals for the BF process should not be underestimated, taking into account the large volume of coke used in BF ironmaking.

The behaviour of mineral-related phosphorus under elevated temperatures of coking and BF processes depends on the decomposition and transformation temperatures of phosphorus-bearing minerals. Earlier, we reported briefly the occurrence of phosphorus in BF coke in the form of schreibersite $\left(\mathrm{Fe}_{3} \mathrm{P}\right)$ and barringerite $\left(\mathrm{Fe}_{2} \mathrm{P}\right) .{ }^{[15]}$ However, the details of reactions involving phosphorus-bearing minerals in the carbon-dominated environment of a coke oven and the BF, the amount and occurrence of mineral-related phosphorus at the end of the coke formation process, as well as the occurrence and behavior of phosphorus-bearing mineral phases during the BF process have not been reported in detail in the literature. In this paper, we describe the results of investigations of the occurrence of major phosphorus-bearing minerals in coking coals and their transformations in feed coke and in the BF process. 


\section{Tools and methods}

Samples of coking coals, feed coke and BF coke were obtained from SSAB Europe Ltd., Finland. The coals are represented by Jas Mos coal from Poland, Willow Creek coal from Canada, Riverside coal from Australia, and Severnaya-Vorkuta coal from Russia. The supplied coals contain 0.0060.057 wt. \% of phosphorus (O. Kerkkonen, personal communication). The samples of BF coke were obtained by tuyere drilling.

Polished sections of four types of coking coals (fractions 1-2.38 mm, 100+ pieces per section), metallurgical coke and BF coke have been investigated using a Jeol JSM-6400 scanning electron microscope (SEM) and a Zeiss ULTRA plus field-emission scanning electron microscope (FESEM) equipped with an energy dispersive spectrometer (semi-quantitative EDS analysis).

In addition to that, thermodynamic calculations were done with FactSage software ${ }^{[16]}$ (version 7.2) in order to trace the behavior of mineral-related phosphorus under elevated temperatures. The conditions for the calculations were the same as we used for the investigation of the behavior of alkali- and sulfur-bearing minerals in metallurgical coke. ${ }^{[17,18]}$ The compositions of the coke oven and BF gas were taken from Liao et al. ${ }^{[19]}$ and Quinn et al., ${ }^{[20]}$ respectively. Stoichiometric compositions of phosphorus-bearing mineral phases were used as initial values for the calculations as they were presented in the FactSage database. ${ }^{[16]}$ The system for the calculations was defined in order to simulate the conditions that phosphorous-bearing minerals hosted by the carbon-dominated environment of coals undergo during the coking and BF processes. It was defined as consisting of: 1) $100 \mathrm{~g}$ of carbon, $100 \mathrm{~g}$ of mineral (one at a time) and $100 \mathrm{~g}$ of gas for the coke oven and 2) $1 \mathrm{~g}$ of carbon, $1 \mathrm{~g}$ of minerals, $1 \mathrm{~g}$ of iron, and $\pm 100 \mathrm{~g}$ of gas for the BF (two scenarios, see 3.3 for the description). The purpose of the calculations was to reveal whether there are driving forces for the changes in mineral compositions (i.e. if the reactions of certain compounds are spontaneous or not). 


\section{Results and discussion}

\subsection{Occurrence of phosphorus-bearing minerals in coking coals}

In order to understand better the behavior of phosphorus-bearing minerals in the feed and BF coke, detailed characterization of their occurrence in a precursor material (coking coals) is needed. According to data in the literature, phosphorus was found in a number of coal-associated minerals. ${ }^{[11-13]}$ The most common phosphorus-bearing minerals in coals are phosphates (apatite major phase, monazite and xenotime) and hydrophosphates (crandallite, gorceixite and goyazite) (Table 1). Apatite has F-, Cl- and/or $\mathrm{H}_{2} \mathrm{O}$-bearing varieties, ranging from zero up to 1.24, 2.32 and 0.59 wt. \% respectively.

Table 1. Stoichiometric compositions (wt. \%) of some phosphorus-bearing minerals

\begin{tabular}{|c|c|c|c|c|c|c|c|c|c|c|c|}
\hline Mineral & $\mathrm{P}_{2} \mathrm{O}_{5}$ & $\mathrm{CaO}$ & $\mathrm{F}$ & $\mathrm{Al}_{2} \mathrm{O}_{3}$ & $\mathrm{BaO}$ & $\mathrm{SrO}$ & $\mathrm{Ce}^{*}$ & $\mathrm{Yb}_{2} \mathrm{O}_{3}$ & $\mathrm{H}_{2} \mathrm{O}$ & $\mathrm{Cl}$ & Formulae \\
\hline Apatite & 41.82 & 55.07 & 1.24 & & & & & & 0.59 & 2.32 & $\mathrm{Ca}_{5}\left(\mathrm{PO}_{4}\right)_{3}(\mathrm{~F}, \mathrm{Cl}, \mathrm{OH})$ \\
\hline Monazite & 29.55 & & & & & & 70.45 & & & & $\mathrm{CePO}_{4}$ \\
\hline Xenotime & 26.48 & & & & & & & 64.56 & & & $\mathrm{YbPO}_{4}$ \\
\hline Crandallite & 34.28 & 13.54 & & 36.94 & & & & & 15.23 & & $\mathrm{CaAl}_{3}\left(\mathrm{PO}_{4}\right)_{2}(\mathrm{OH})_{5} \times \mathrm{H}_{2} \mathrm{O}$ \\
\hline Gorceixite & 27.76 & & & 29.91 & 29.99 & & & & 12.33 & & $\mathrm{BaAl}_{3}\left(\mathrm{PO}_{4}\right)_{2}(\mathrm{OH})_{5} \times \mathrm{H}_{2} \mathrm{O}$ \\
\hline Goyazite & 30.75 & & & 33.14 & & 22.45 & & & 13.66 & & $\mathrm{SrAl}_{3}\left(\mathrm{PO}_{4}\right)_{2}(\mathrm{OH})_{5} \times \mathrm{H}_{2} \mathrm{O}$ \\
\hline
\end{tabular}

Data from. ${ }^{[16,21]} * \mathrm{Ce}\left(\mathrm{Ce}_{2} \mathrm{O}_{3} \pm \mathrm{La}_{2} \mathrm{O}_{3} \pm \mathrm{Sm}_{2} \mathrm{O}_{3} \pm \mathrm{Gd}_{2} \mathrm{O}_{3} \pm \mathrm{ThO}_{2} \pm \mathrm{Nd}_{2} \mathrm{O}_{3}\right)$.

The investigations of our samples of coking coals with SEM, FESEM and EDS analysis found three phosphorus-bearing minerals: gorceixite, monazite and apatite. However, the first two minerals are quite rare in coals in general, and only a few grains were found in the samples. For that reason, they have not been considered for thermodynamic calculations in this study (they are also not yet available in the FactSage database).

Gorceixite (Figure 1a, Table 2, analyses 1 and 2) occurs in in the form of grains of 10-20 $\mu \mathrm{m}$ in size with elliptical or irregular shapes, and it is associated with complex aluminosilicates. The grain of monazite (Figure 1b, Table 2, analysis 3) has smooth outlines and, as surrounded aluminosilicates, has a signs of breakage. 

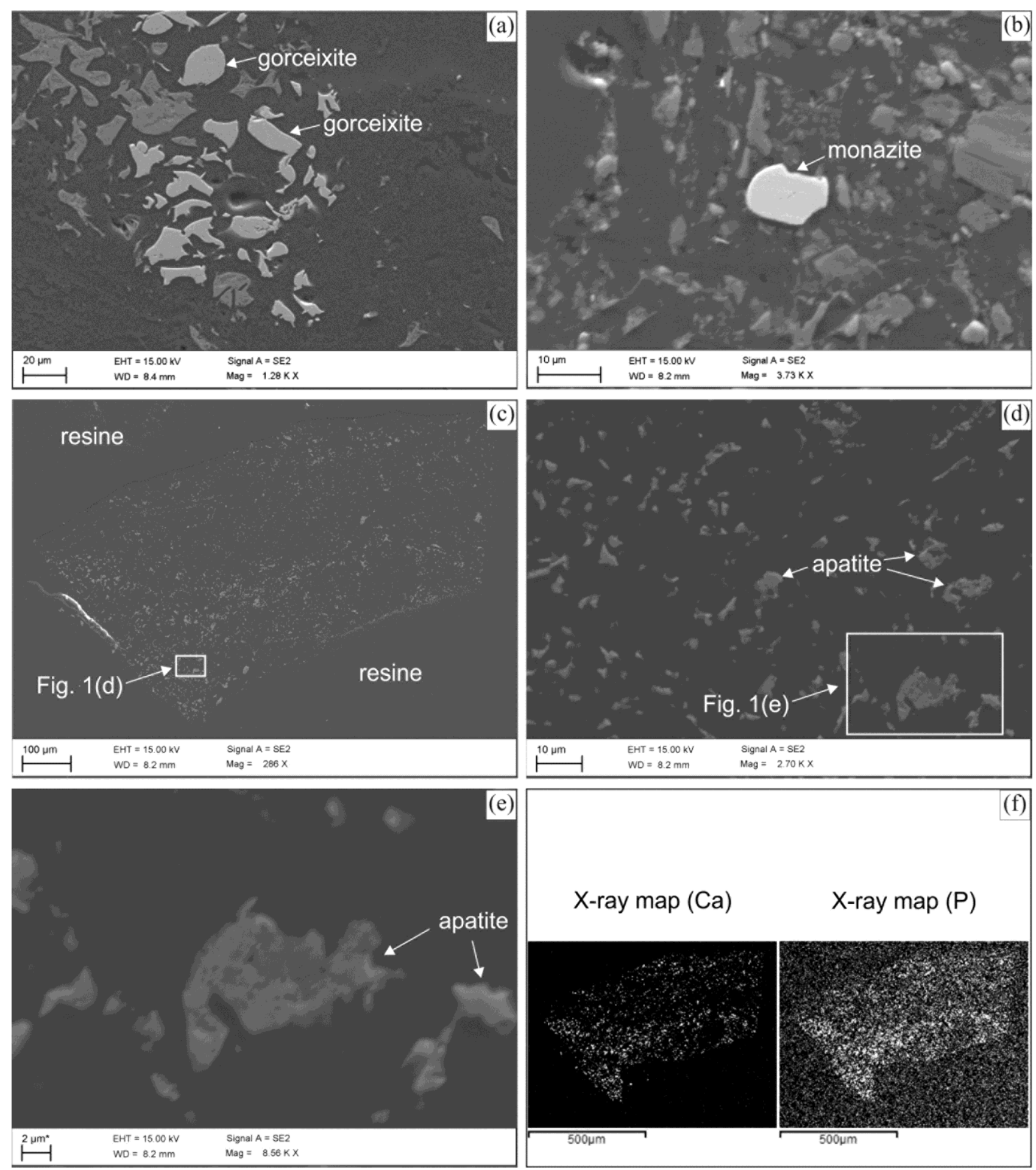

Figure 1. Occurrence of phosphorus-bearing minerals in coking coals. 1(f) - X-ray map of the area shown in $1(\mathrm{c})$. See text for details. 
Apatite is the most common phosphorus-bearing mineral found in the samples. It occurs as separate grains or their aggregates in a coal matrix or in association with other minerals (Figures 1c1f, Table 2, analysis 4). In some cases, sharp crystal edges of the mineral have been observed. The size of the aggregates varies from 10 to $50 \mu \mathrm{m}$, while individual crystals are 3-10 $\mu \mathrm{m}$ in size, but often less. For that reason, reliable EDS analyses in many cases have not been possible and the mineral has been identified by spectra and relative amounts of elements. X-ray mapping for Ca and $\mathrm{P}$ (Figure 1f) and subsequent EDS analyses of the mineral-rich area presented in Figure 1c show that it is filled by numerous tiny grains of apatite. However, such enriched areas are rare, and the mineral was found in the samples mostly in the form of single grains associated with aluminosilicates or surrounded by a carbon matrix. It should also be mentioned that natural alteration of coals and associated minerals is a common process that leads to partial or complete alteration and/or decomposition of some minerals, and as a result, also complicates their identification.

Table 2. EDS analyses (wt. \%, normalized) of altered phosphorus-bearing minerals in coals and coke

\begin{tabular}{l|ccccc}
\hline & $\mathrm{P}_{2} \mathrm{O}_{5}$ & $\mathrm{CaO}$ & $\mathrm{Al}_{2} \mathrm{O}_{3}$ & $\mathrm{BaO}$ & $\mathrm{Ce}^{*}$ \\
\hline 1 & 24.82 & 0.78 & 23.78 & 20.48 & \\
2 & 24.98 & 1.63 & 24.23 & 18.36 & \\
3 & 35.72 & 1.51 & & & 62.76 \\
4 & 42.46 & 57.54 & & & \\
5 & 44.58 & 55.42 & & & \\
\hline
\end{tabular}

$* \mathrm{Ce}=\mathrm{Ce}_{2} \mathrm{O}_{3}+\mathrm{La}_{2} \mathrm{O}_{3}+\mathrm{ThO}_{2}+\mathrm{Nd}_{2} \mathrm{O}$. 1) Gorceixite - Willow Creek, Canada (Figure 1a - elongated lenticular grain); 2) Gorceixite - Willow Creek, Canada (Figure 1a, elliptical grain); 3) Monazite - Severnaja, Russia (Figure 1b); 4) Apatite - Jas Mos, Poland (Figure 1e, irregular grain on the right side of the image); 5) Ca-P-O phase, coke (Figure 2b). $\mathrm{F}, \mathrm{H}_{2} \mathrm{O}$ and $\mathrm{Cl}$ have not been detected. 


\subsection{Occurrence of phosphorus-bearing minerals during the formation of metallurgical coke}

Under coke oven conditions (temperatures up to $1200{ }^{\circ} \mathrm{C}$ ), coal-associated minerals go through phase transformations and decomposition. The later include dehydration, dehydroxylation, decarbonation and desulfurization, ${ }^{[22]}$ so the initial composition may change substantially.

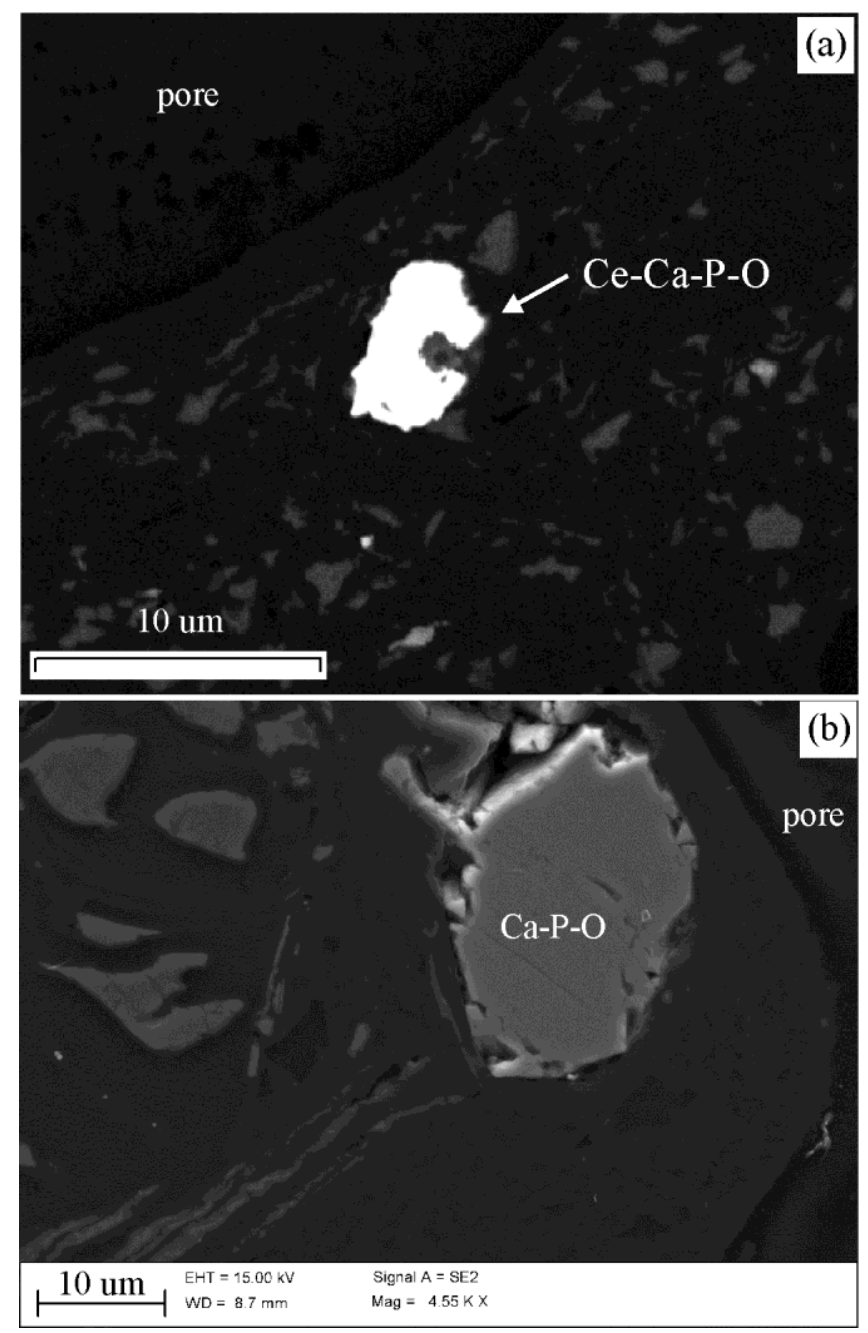

Figure 2. Phosphorous-bearing phases in metallurgical coke: (a) Ce-Ca-P-O (SEM Jeol JSM-6400), (b) Ca-P-O (FESEM Zeiss ULTRA plus), Table 2, analysis 5.

In the samples of coke studied, phosphorus was found in the form of scarce grains of $\mathrm{Ce}(\mathrm{Nd}, \mathrm{Th})$ Ca-P-O phase and, more often, as Ca-P-O phases (Figures $2 \mathrm{a}$ and $2 \mathrm{~b}$ ). The Ce-Ca-P-O phase (Figure 2a) is about $3 \times 6 \mu \mathrm{m}$ in size, and it gave low total (74.08 wt. \%) by EDS analysis. The following elements were detected in the spectra (at. \%, normalized): O (77.18), P (15.02), Ca (0.8), Ce (4.25), Nd (2.14) and Th (0.6). Such atomic proportions most likely belong to altered monazite, 
which was also found in the samples of coal. The grain of Ca-P-O shown in Figure 2(b) is $20 \times 40$ $\mu \mathrm{m}$, and it was likely formed after apatite (Table 2, analysis 5). It should be noted that the size of phosphorus-bearing phases in metallurgical coke is controlled by the original grain size of the minerals in any particular coal.

Thermodynamic calculations have shown (Figure 3) that unlike aluminosilicates, ${ }^{[17,22]}$ apatite occurring in coals will fully transform into other phases already at coking temperatures. For that reason, this mineral cannot be found in metallurgical coke in primary form, and it will be represented by Ca-P-O phases (Figure 2a). The details of the calculations indicate that the formation of $\mathrm{Ca}_{4} \mathrm{P}_{2} \mathrm{O}_{9}$ will start at $1060{ }^{\circ} \mathrm{C}$, while the other phase, $\mathrm{Ca}_{3} \mathrm{P}_{2} \mathrm{O}_{8}$, will fully replace the rest $(77.37$ wt. \%) of apatite remaining in the system at $1164{ }^{\circ} \mathrm{C}$.

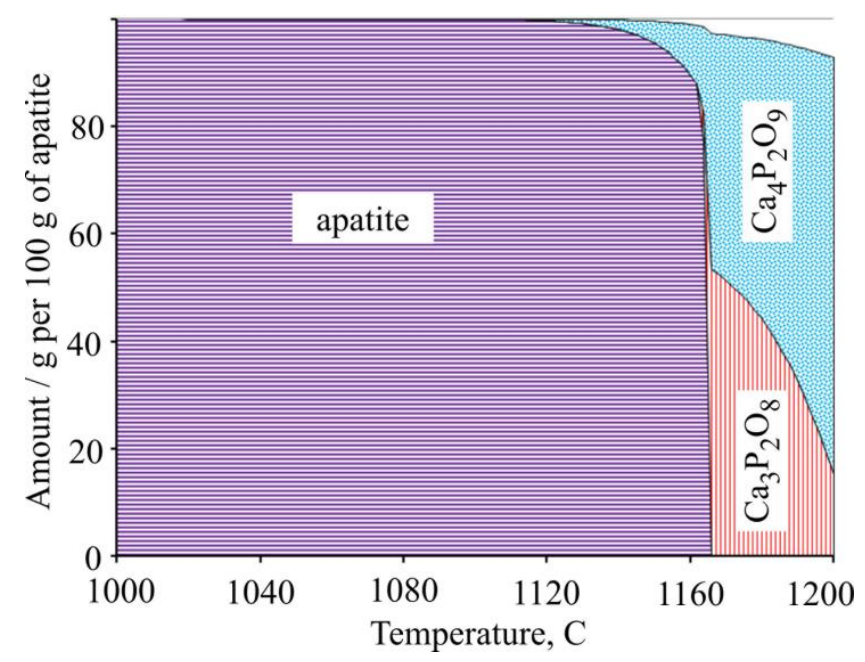

Figure 3. Transformation of apatite in mineral-carbon-gas system during the formation of coke (section for $1000-1200{ }^{\circ} \mathrm{C}$ ). 


\subsection{Occurrence and behaviour of phosphorus-bearing minerals in metallurgical coke under BF conditions}

In the samples of BF coke, phosphorus-bearing phases have been found in two varieties (Figure 4). The first (Figures $4 \mathrm{a}$ and $4 \mathrm{~b}$ ) is represented by relatively rare grains of about $20 \mu \mathrm{m}$ in size, which have smooth outlines and porous surface. Circular outlines of Fe-P phase shown in Figure 4a clearly indicate that the grain has been in a molten state. EDS analyses (Table 3, analyses 1 and 2) give a low total due to properties of the surface, so the phases cannot be identified with certainty. However, atomic proportions of phosphorus and iron indicate that the first one is probably $\mathrm{Fe}_{3} \mathrm{P}$, while the second is likely to be $\mathrm{Fe}_{2} \mathrm{P}$. The EDS spectrum of the phases also includes trace amounts of sulfur, which is likely related to the presence of sulfur-bearing minerals, which are common in the original coking coals. ${ }^{[18]}$ The second variety of Fe-P phases is more common, and it often forms spherical inclusions in the matrix of coke (Figures $4 \mathrm{c}$ and $4 \mathrm{~d}$ ). These inclusions are 5-30 $\mu \mathrm{m}$ with a smooth surface and outlines. Their composition (Table 3, analyses 3-6) is close to stoichiometric $\mathrm{Fe}_{3} \mathrm{P}$. In BF coke, melting of Fe-P phases can lead to small particles joining to larger ones, and then they can easily slide along pieces of the BF coke down to the lower levels of the BF.
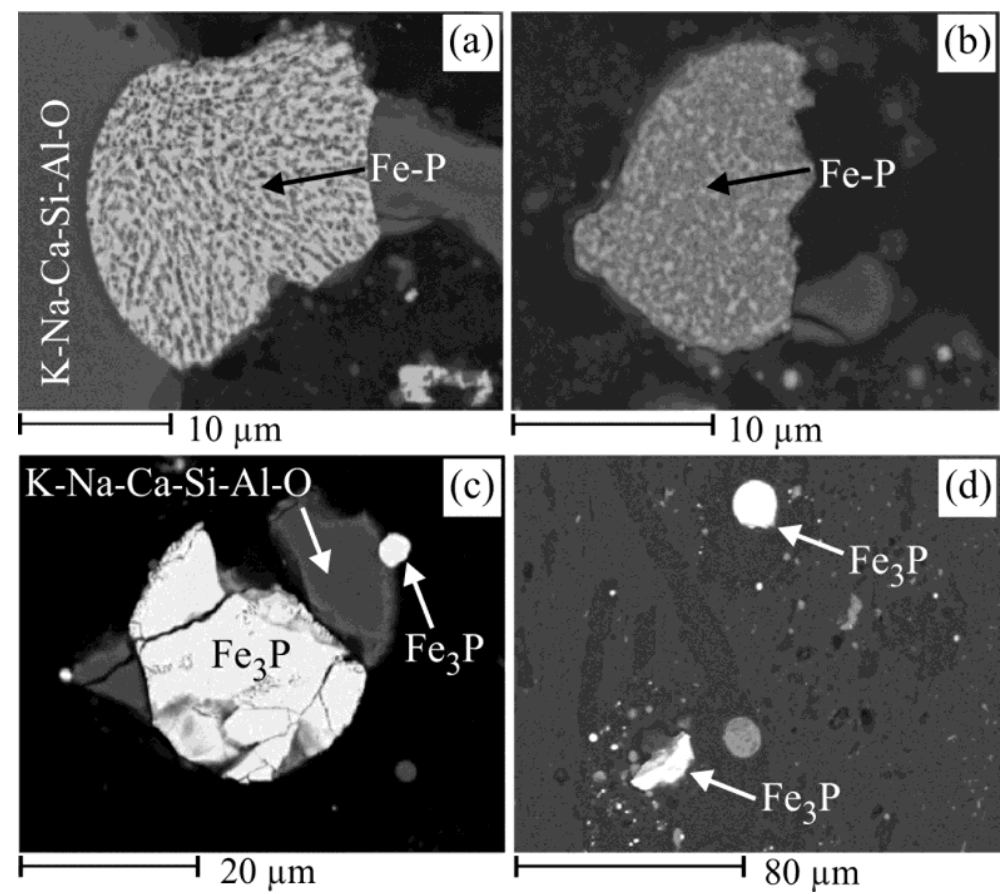

Figure 4. $\mathrm{Fe}-\mathrm{P}(\mathrm{a}, \mathrm{b})$ and $\mathrm{Fe}_{3} \mathrm{P}(\mathrm{c}, \mathrm{d})$ phases in the BF coke. SEM Jeol JSM-6400. See Table 3 for analyses. 
Table 3. Compositions (wt. \%) of phosphorus-bearing phases in the BF coke

\begin{tabular}{c|cccc}
\hline & $\mathrm{S}$ & $\mathrm{P}$ & $\mathrm{Fe}$ & sum \\
\hline 1 & 0.47 & 4.11 & 87.58 & 92.17 \\
2 & 0.48 & 6.99 & 77.32 & 84.78 \\
3 & - & 15.95 & 83.61 & 99.56 \\
4 & - & 15.29 & 81.00 & 96.29 \\
5 & - & 14.04 & 83.91 & 97.95 \\
6 & - & 13.91 & 84.70 & 98.61 \\
\hline
\end{tabular}

1) Fe-P phase (low total, not defined), Figure 4a; 2) Fe-P phase (low total, not defined), Figure 4b; 3) $\mathrm{Fe}_{3} \mathrm{P}$ - Figure 4c (small inclusion; 4) $\mathrm{Fe}_{3} \mathrm{P}$ - Figure $4 \mathrm{c}$ (big inclusion; 5) $\mathrm{Fe}_{3} \mathrm{P}$ - Figure $4 \mathrm{~d}$ (elongated inclusion); 6) $\mathrm{Fe}_{3} \mathrm{P}$ - Figure $4 \mathrm{~d}$ (rounded inclusion).

Thermodynamic calculations simulating the BF conditions were made for two scenarios. The system for the first one was defined as: $1 \mathrm{~g}$ of carbon $+1 \mathrm{~g}$ of minerals $+1 \mathrm{~g}$ of iron without a BF gas phase (closed system inside coke pieces or in places with limited circulation of the BF gas). The source of iron in this case is iron-bearing minerals hosted by the coke matrix together with phosphorous-bearing phases. The second scenario has been calculated under the following conditions: $1 \mathrm{~g}$ of carbon $+1 \mathrm{~g}$ of minerals $+1 \mathrm{~g}$ of iron $+100 \mathrm{~g}$ of BF gas, suggesting an intensive gas flow (open system). The sources of iron in this case are coke-associated minerals and the burden material.

In the case of a closed system (Figure 5a), phosphorus is presented in the form of two Ca-P-O phases $\left(\mathrm{Ca}_{4} \mathrm{P}_{2} \mathrm{O}_{9}\right.$ and $\left.\mathrm{Ca}_{3} \mathrm{P}_{2} \mathrm{O}_{8}\right)$ up to $1250{ }^{\circ} \mathrm{C}$. The later phase has two varieties - "I" and "II" (not specified in the FactSage program). Above this temperature, phosphorus occurs in the form of $\mathrm{Fe}_{3} \mathrm{P}$, which is stable until $1495{ }^{\circ} \mathrm{C}$. Further rises in temperature lead to the transformation of $\mathrm{Fe}_{3} \mathrm{P}$ to $\mathrm{Fe}_{2} \mathrm{P}$, which exists up to $1930{ }^{\circ} \mathrm{C}$ (corresponds to the tuyere level of the BF). So, phosphorous presented in mineral inclusions inside coke pieces will remain there in the form of solid phases until the coke reaches the tuyere level of the BF. We also believe that the conditions of closed system can be realized not only inside pieces of coke, but also in some places within burden materials where the circulation of $\mathrm{BF}$ gas is limited. Under such conditions, solid phosphorus-bearing phases will exist at relatively low levels of the BF. 
In the case of an open system (Figure 5b) with an intensive gas flow, the formation of $\mathrm{Fe}_{3} \mathrm{P}$ from $\mathrm{Ca}_{4} \mathrm{P}_{2} \mathrm{O}_{9}$ and $\mathrm{Ca}_{3} \mathrm{P}_{2} \mathrm{O}_{8}$ starts at $1178{ }^{\circ} \mathrm{C}$. The other important difference from the closed system is that $\mathrm{Fe}_{2} \mathrm{P}$ will appear only near $1494-1495{ }^{\circ} \mathrm{C}$ (shown in Figure $5 \mathrm{~b}$ by an arrow) and, after that, it will go to a molten state. Therefore, phosphorus in this case will not exist in solid phases at the tuyere level.
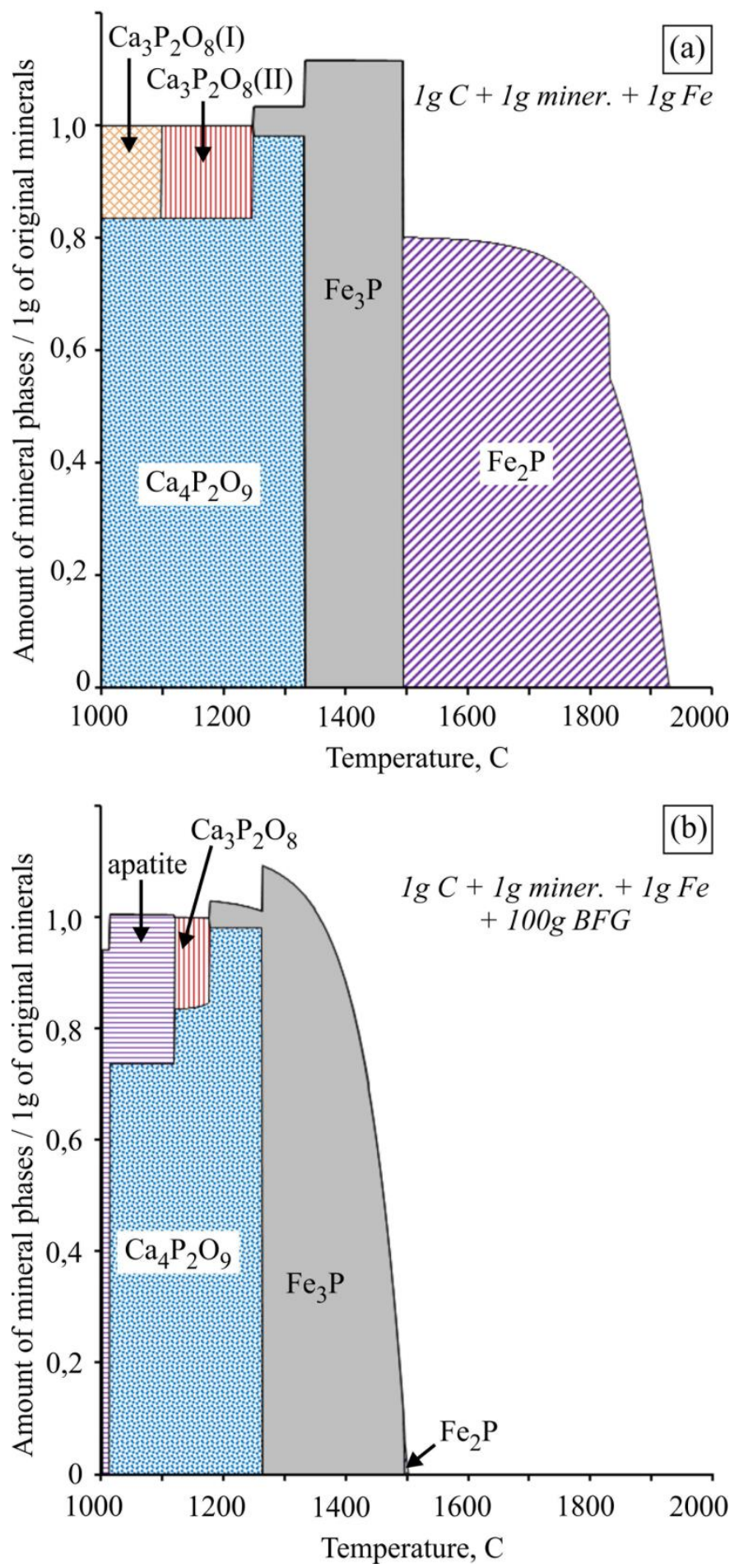

Figure 5. Transformations of $\mathrm{Ca}_{4} \mathrm{P}_{2} \mathrm{O}_{9}$ and $\mathrm{Ca}_{3} \mathrm{P}_{2} \mathrm{O}_{8}$ to $\mathrm{Fe}_{3} \mathrm{P}$ and $\mathrm{Fe}_{2} \mathrm{P}$ under the $\mathrm{BF}$ conditions: (a) - closed system (no gas), (b) - open system with gas phase. 


\section{Conclusion}

Based on the observations and discussion above, the findings can be summarized as follows:

- The major coal-associated phosphorus-bearing minerals include phosphates (apatite - main phase, monazite and xenotime) and hydrophosphates (crandallite, gorceixite and goyazite).

- Apatite fully transforms to other Ca-P-O phases at coking temperatures. Thermodynamic calculations indicate that the formation of $\mathrm{Ca}_{4} \mathrm{P}_{2} \mathrm{O}_{9}$ will start at $1060{ }^{\circ} \mathrm{C}$, while $\mathrm{Ca}_{3} \mathrm{P}_{2} \mathrm{O}_{8}$ will fully replace the rest of apatite at $1164{ }^{\circ} \mathrm{C}$, which corresponds to the end of the coking process.

- In the case of a closed system (no gas) in the BF, phosphorus is presented in the form of two Ca-P-O phases $\left(\mathrm{Ca}_{4} \mathrm{P}_{2} \mathrm{O}_{9}\right.$ and $\left.\mathrm{Ca}_{3} \mathrm{P}_{2} \mathrm{O}_{8}\right)$ up to $1250{ }^{\circ} \mathrm{C}$. Above this temperature, it will occur in the form of $\mathrm{Fe}_{3} \mathrm{P}$ (stable until $1495^{\circ} \mathrm{C}$ ). Further rises in temperature lead to the transformation of $\mathrm{Fe}_{3} \mathrm{P}$ to $\mathrm{Fe}_{2} \mathrm{P}$ (stable up to $1930{ }^{\circ} \mathrm{C}$, which corresponds to the tuyere level of the $\mathrm{BF}$ ). The grains of $\mathrm{Fe}_{3} \mathrm{P}$ and $\mathrm{Fe}_{2} \mathrm{P}$ in the samples of $\mathrm{BF}$ coke are about 5-30 $\mu \mathrm{m}$ in size. The conditions of a closed system can be realized inside pieces of coke and in some places within burden materials where the circulation of the BF gas is limited. Under such conditions, solid phosphorus-bearing phases will exist at relatively low levels of the BF.

- In the case of an open system in the $\mathrm{BF}$ with intensive gas flow, the formation of $\mathrm{Fe}_{3} \mathrm{P}$ from $\mathrm{Ca}_{4} \mathrm{P}_{2} \mathrm{O}_{9}$ and $\mathrm{Ca}_{3} \mathrm{P}_{2} \mathrm{O}_{8}$ will start at $1178{ }^{\circ} \mathrm{C}$. $\mathrm{Fe}_{2} \mathrm{P}$ will appear only near $1494-1495{ }^{\circ} \mathrm{C}$, and after that it will go to a molten state. Therefore, phosphorus in this case will not exist in solid phases at the tuyere level.

\section{Acknowledgements}

This research was funded by the Academy of Finland. The samples were provided by SSAB Europe Ltd. (Raahe, Finland). We thank Mr. Tommi Kokkonen for preparing the samples. 


\section{References}

[1] H. Kaneko, T. Nishizawa, K. Tamaki, A. Tanifuji, Journal of the Japan Institute of Metals and Materials 1965, 29, 166. doi.org/10.2320/jinstmet1952.29.2_166

[2] H. Hu, Texture of Crystalline Solids 1976, 2, 113. doi.org/10.1155/TSM.2.113

[3] M. Wettlaufer, R. Kaspar, Steel Research 2000, 71, 357. doi.org/10.1002/srin.200001329

[4] J. Bouquerel, K. Verbeken, D. Krizan, L. Barbe, P. Verleysen, Y. Houbaert, Steel Res. Int. 2008, 79, 784. doi.org/10.1002/srin.200806199

[5] N. Li, Z. Liu, G. Zhou, X. Liu, G. Wang, Int. J. Miner. Metall. Mater. 2010, 17, 417. doi.org/10.1007/s12613-010-0334-4

[6] M. Jafari, Y. Kimura, K. Tsuzaki, Philosophical Magazine Letters 2013, 93, 109. doi.org/10.1080/09500839.2012.750766

[7] Y. Zhao Y., S. Song, Steel Res. Int. 2018, 89, 1800096 (on-line). doi.org/10.1002/srin.201800096

[8] F. Pahlevani, S. Kitamura, H. Shibata, N. Maruoka, Steel Res. Int. 2010, 81, 617. doi.org/10.1002/srin.201000053

[9] H. Zhou, Y. Bao, L. Lin, Steel Res. Int. 2013, 84, 863. doi.org/10.1002/srin.201200231

[10] B. Ryan, M. Khan, Maceral Affinity of Phosphorus in Coals from the Elk Valley Coalfield, British Columbia. In: Geological Fieldwork 1997, B.C. Ministry of Employment and Investment, Victoria, Canada 1998, Paper 1998-1, p. 28-1.

www.researchgate.net/publication/265306421

[11] C. R. Ward, J. F. Corcoran, J. D. Saxby, H. W. Read, Int. J. of Coal Geol. 1996, 30, 185. doi.org/10.1016/0166-5162(95)00055-0

[12] C. R. Ward, Int. J. of Coal Geol. 2002, 50, 135. doi.org/10.1016/S0166-5162(02)00117-9

[13] H. Tu, W. Li, X. Bai, J. of Fuel Chemistry and Technology 2011, 39, 641. doi.org/10.1016/S1872-5813(11)60039-X

[14] S. Dai, J. C. Hower, C. R. Ward, W. Guo, H. Song, J. M. K. O'Keefe, P. Xie, M. M. Hood, X. Yan, Int. J. of Coal Geol. 2015, 144-145, 23. doi.org/10.1016/j.coal.2015.04.002

[15] S. Gornostayev, J. Härkki, Metall. Mater. Trans. B 2005, 36B, 303. doi.org/10.1007/s11663-005-0032-1

[16] C. W. Bale, P. Chartrand, S. A. Degterov, G. Eriksson, K. Hack, R. Ben Mahfoud, J. Melancon, A. D. Pelton, S. Petersen, Calphad 2002, 26, 189.

doi.org/10.1016/S0364-5916(02)00035-4

[17] Gornostayev S.S., Heikkinen E-P., Heino J.J., Hutunen S.M.M., Fabritius T.M.J., Steel Res. Int. 2016, 87, 1144. doi.org/10.1002/srin.201500295

[18] Gornostayev S., Heikkinen E-P., Heino J., Fabritius T., Steel Res. Int. 2018, 89 (on-line) 
[19] H. Liao, B. Li, B. Zhang, Fuel 1998, 77, 1643. doi.org/10.1016/S0016-2361(98)00076-3

[20] G. Quinn, B. Faraj, R. Callcott and T. Callcott, Elucidation of the effects of minerals on coke behaviour in the blast furnace, Australian Coal Association Research Program, Project C10054, Australian Coal Research Limited, Brisbane, Australia 2002, pp. 1-80.

[21] Mineral species containing phosphorus (P), webmineral.com/chem/Chem-P.shtml (verified by 2018-11-11).

[22] S. S. Gornostayev, O. Kerkkonen, J. J. Härkki, Steel Res. Int. 2009, 80, 390. doi.org/10.2374/SRI09SP007 